\title{
Teatro romântico e escravidão
}

\section{João Roberto Faria}

Resumo: Como o teatro brasileiro dos tempos românticos representou o negro e a escravidão nos palcos e nos textos dramáticos? $\mathrm{O}$ artigo tenta dar uma resposta a essa questão - passando em revista as principais obras e autores que a abordaram -, a partir de uma sugestão colhida em texto de Brito Broca, para quem a literatura brasileira fez abolicionismo romântico e realista. Palavras-chave: teatro romântico, teatro realista, história do teatro brasileiro.

Abstract: How did the Brazilian theatre of a romantic epoch represent the Negro and the slavery on the stage and dramatic texts? The article tries to give an answer to that question, by going through the main works and authors that focused on the question, beginning with a suggestion found in a text by Brito Broca, to whom the Brazilian literature created a romantic and realistic abolitionism. Keywords: romantic theatre, realistic theatre, history of the Brazilian theatre. 
Meu ponto de partida para esta breve apresentação é o artigo de Brito Broca, intitulado "O bom escravo e As vítimas-algozes", escrito em 1958 e publicado no livro Românticos, pré-românticos, ultrarromânticos. ${ }^{1}$

Ele comenta algumas obras que abordaram a questão da escravidão, no período romântico, e formula a seguinte hipótese: a propaganda abolicionista se fez na literatura de duas maneiras: em uma "mostrando o escravo como uma criatura cheia de virtudes, superando os males da instituição; noutra mostrando-o como um ser infeliz e miserável, levado ao vício ou ao crime por culpa exclusiva do cativeiro. No primeiro caso temos uma imagem idealizada e romântica do negro, que o torna até superior ao branco. No segundo, uma imagem realista: o escravo dificilmente poderia ser bom na condição nefanda a que o relegava o cativeiro".

Brito Broca diz ainda que o protótipo do escravo idealizado surge com o romance $A$ cabana do pai Tomás, de Harriet Beecher Stowe, em 1852, com o qual o abolicionismo romântico ganha impulso. Trata-se de um "abolicionismo que pretendia inspirar o horror ao cativeiro por meio da exaltação do escravo". A essa linhagem pertence o romance A escrava Isaura, de Bernardo Guimarães (1875), e a peça teatral Mãe (1860), de José de Alencar. Ao abolicionismo realista, para usar os termos do autor, pertencem a comédia $O$ demônio familiar (1857), de José de Alencar, e as novelas intituladas As vítimas-algozes (1869), de Joaquim Manuel de Macedo. Brito Broca acrescenta ainda duas obras posteriores ao período romântico em que se encontra o abolicionismo realista: O escravocrata, drama de Artur Azevedo e Urbano Duarte, e A carne, romance de Júlio Ribeiro.

É evidente que Brito Broca não esgotou o assunto. Tendo escrito um artigo curto, deu poucos exemplos para ilustrar sua ideia. Se quisermos avançar no mesmo caminho indicado por ele, buscando outras obras e pensando na diferença entre o abolicionismo romântico e o realista, logo de cara perceberemos que quase não temos outros exemplos no terreno do romance. O negro, liberto ou escravo, não ocupou o centro das narrativas em nossa literatura romântica. Além da escrava Isaura que era branca, como todos sabem - e dos negros que protagonizam as novelas de Macedo, outros personagens que poderiam ser lembrados só desempenham papéis secundários. É o caso do moleque Tobias, de A moreninha, de Macedo; de Vidinha, mulata não escrava das Memórias de um sargento de milícias, de Manuel Antônio de Almeida; ou de Joaninha, a mulata sedutora de As minas de prata, de José de Alencar. Não há críticas à escravidão nessas obras ou em outras de Bernardo Guimarães,

BROCA, Brito. Românticos, pré-românticos, ultrarromânticos. São Paulo: Polis/INL, 1979, p. 271-3. 
em que o negro é personagem: Lendas e romances, Rosaura, a enjeitada, Maurício e O garimpeiro. Raymond Sayers, no livro O negro na literatura brasileira, menciona alguns escritores menos conhecidos como autores de obras antiescravistas: Pinheiro Guimarães ( $O$ comendador, 1856), José Silva Pereira (Cenas do interior, 1865); Júlio Leal (Cenas da escravidão, 1873).

Se o romance romântico não fez do negro e da escravidão assuntos centrais, preferindo o índio, os costumes urbanos da burguesia, os costumes do interior do país e o passado histórico, o teatro não se fez de rogado. Lembremos, para começar, que não há nenhum herói negro nos romances de Alencar, mas o escravo protagoniza duas de suas peças teatrais, consideradas antiescravistas por Brito Broca.

Antes de Alencar, também o teatro romântico fez do negro e do escravo personagens secundários, importantes apenas para dar às peças a tão desejada cor local na reconstituição dos costumes. Nas comédias de Martins Pena, representadas no final dos anos 1830 e ao longo da década de 1840, a escravidão surge eventualmente como pano de fundo da ação, e por vezes o autor vai além do registro cômico, apontando aqui e ali a sua ignomínia. Como afirma Vilma Arêas, os escravos, "desvestidos de características humanas, sem voz e sem razão, são vistos a trabalhar o tempo todo, chicoteados, empurrados, enganados, enquanto, um palmo acima, a trama desenrola-se e os demais personagens giram segundo o vivíssimo ritmo desse teatro".

Um bom exemplo dos maus-tratos a que eram submetidos os escravos está na comédia Os dois ou O inglês maquinista. A certa altura, a personagem Clemência interrompe a conversa que está tendo com amigos, pois ouve barulho de louça quebrada. Ela vai à cozinha, nos bastidores, e chicoteia as escravas pela louça que na verdade havia sido quebrada por um cão. Em seguida entra em cena quase sem fôlego, dizendo que não gosta "de dar pancada". Em várias outras comédias o escravo aparece como figurante, o que levou Sílvio Romero a observar que "uma das máculas nacionais que mais vivamente aparecem nas comédias do nosso compatriota é, sem dúvida, a escravidão". E mais: "Não há nenhuma de suas obras conhecidas em que direta ou indiretamente ela não apareça; não há nenhuma em que não exista alguma referência à nefanda instituição por palavras que seja. Os termos preto, negro, escravo, moleque, mucama, meia-cara lá estarão, ao menos para dar testemunho do fato"3

ARÊAS, Vilma Sant'Anna. Na tapera de Santa Cruz: uma leitura de Martins Pena. São Paulo: Martins Fontes, 1987, P. 26. 
As comédias de Martins Pena, nascidas da observação da vida social, registram os costumes brasileiros de seu tempo, mas principalmente das camadas populares, dos homens brancos e pobres. Quando o escravo surge em cena, ainda que de modo degradado e rebaixado, não há uma crítica contundente ou explícita nos diálogos ou nas ações dos personagens, que nos permita enxergar uma posição clara do autor contra o cativeiro.

O mesmo se pode dizer do negro que aparece no drama O cego, de Joaquim Manuel de Macedo, representado em 1849. O personagem Daniel é um guia de cego e tem papel secundário na trama, em cujo centro estão dois irmãos que amam a mesma mulher. Não há aqui nenhuma preocupação com o problema da escravidão, que o autor abordará nas novelas As vítimas-algozes, vinte anos depois, com forte colorido abolicionista. O que talvez explique tal discrepância seja o fato de que, na época em que $O$ cego foi encenado, a própria ideia da abolição da escravidão não estava na ordem do dia. Nem mesmo o Partido Liberal tinha simpatias pelo fim do cativeiro, que, no entanto, estava com os seus dias contados a partir justamente de 1850, com a interrupção do tráfico de escravos. O choque na economia foi brutal e redesenhou a vida urbana do país, que ganhou investimentos vultosos, antes destinados à compra de escravos. Uma prova curiosa de que essas mudanças provocaram protestos é uma comédia publicada no mesmo ano de 1850: Os ingleses no Brasil. O autor, José Lopes de La Vega, espanhol radicado no Brasil, escreveu-a para criticar a extinção do tráfico de escravos.

Com as transformações econômicas que se dão ao longo da década de 1850, forma-se no Brasil uma pequena burguesia que passa a ver com bons olhos as ideias liberais. A partir de 1855, o Teatro Ginásio Dramático, no Rio de Janeiro, passa a encenar várias peças francesas que apresentam com cores muito positivas a vida burguesa e seus valores éticos, como o trabalho, o casamento e a família. A escravidão nos separa dessa sociedade avançada, civilizada, algo que incomoda os espíritos jovens. É nesse ambiente que Alencar surpreende todos, depois de fazer sucesso com O guarani, publicado no Diário do Rio de Janeiro, entre janeiro e abril de 1857. Em novembro desse ano ele põe em cena sua segunda comédia, $O$ demônio familiar, trazendo para o centro do palco o escravo doméstico, o moleque Pedro, que arma uma sequência de confusões com suas mentiras, separando jovens que se amam e desestabilizando a família do jovem médico Eduardo. Não há maldade em seus atos: ele quer apenas que seu senhor se case com uma mulher rica para ser cocheiro e vestir um uniforme vistoso. Descoberto, Pedro não é punido com chibatadas ou qualquer outra forma de violência. E nem é posto à venda. Criando um desfecho surpreendente, Alencar faz Eduardo libertar o moleque, colocando em sua boca as seguintes palavras: 
Todos devemos perdoar-nos mutuamente; todos somos culpados por havermos acreditado ou consentido no fato primeiro, que é a causa de tudo isto. O único inocente é aquele que não tem imputação, e que fez apenas uma travessura de criança, levado pelo instinto de amizade. Eu o corrijo, fazendo do autômato um homem; restituo-o à sociedade, porém expulso-o do seio de minha família e fecho-lhe para sempre a porta de minha casa. (a Pedro) Toma: é a tua carta de liberdade, ela será a tua punição de hoje em diante, porque as tuas faltas recairão unicamente sobre ti; porque a moral e a lei te pedirão conta severa de tuas ações. Livre, sentirás a necessidade do trabalho honesto e apreciarás os nobres sentimentos que hoje não compreendes. ${ }^{4}$

Que significado guarda esse desfecho? Uma crítica à escravidão? Para alguns estudiosos, sim. Machado de Assis, por exemplo, considera O demônio familiar e o drama Mãe "um protesto contra a instituição do cativeiro". ${ }^{5}$ Outros críticos, levando em conta que na maturidade Alencar foi político conservador e contrário à abolição abrupta da escravidão, discordam de Machado. Magalhães Júnior, para dar um exemplo, escreve que o final da comédia não passa de uma antecipação da atitude conformista de Alencar, que queria os escravos "fora dos lares e longe das famílias, mas permanecendo nas senzalas e no trabalho forçado dos eitos".6

A verdade é que o julgamento de Magalhães Júnior extrapola os limites da comédia. Em nenhum momento Eduardo dá a entender que é a favor da escravidão não doméstica. O próprio Alencar chegou a escrever sobre o assunto, dizendo que jamais havia aplaudido a escravidão em seus discursos ou escritos, e que a respeitara enquanto lei do país, acrescentando: "[...] manifestei-me sempre em favor de sua extinção espontânea e natural, que devia resultar da revolução dos costumes por mim assinalada. Continuei como político a propaganda feita no teatro".

Podemos concordar com a avaliação de Machado e aceitar os argumentos de Alencar, vendo em sua comédia uma condenação do cativeiro. Mas tenhamos clareza para perceber que $O$ demônio familiar não aprofunda as críticas a essa instituição, que afinal sustentava a economia do país. Alencar quis mostrar unicamente os inconvenientes da escravidão doméstica, tão comum no Brasil urbano de seu tempo, colocando no

ALENCAR, José de. O demônio familiar. Campinas: Editora da Unicamp, 2003, p. 226.

ASSIS, Machado de. Do teatro: Textos críticos e escritos diversos. São Paulo: Perspectiva, 2008, p. 414

MAGALHÃES JÚNIOR, Raimundo. José de Alencar e sua época. 2. ed. Rio de Janeiro: Civilização Brasileira, 1977, p. 119 
centro da ação dramática um escravo travesso, movido por um objetivo fútil. Assim, ele condena esse costume das velhas famílias brasileiras, talvez por duas razões: em primeiro lugar, porque as próprias famílias podiam tornar-se vítimas do escravo doméstico; ou seja, a escravidão não é ruim apenas para o escravo, mas também para o homem branco; em segundo, porque se tratava de costume herdado da tradição colonial. Manter o escravo doméstico, em 1857, era um anacronismo, pelo menos para as famílias modernas dos profissionais liberais que naquela altura viviam de seu trabalho. Eduardo, médico e membro da pequena burguesia emergente de então, dá a liberdade a Pedro e ao mesmo tempo se liberta da última amarra que o prendia à antiga estrutura social. Se entendermos o desfecho dessa maneira, a comédia pode ser lida como uma provocação à sociedade escravista, que não abdica dos costumes que vêm dos tempos coloniais. Eduardo dá o exemplo, no palco, de uma atitude fundamental para a modernização da família brasileira, em termos burgueses. E não só no desfecho, pois toda a sua postura, ao longo da comédia, é de quem se contrapõe aos velhos hábitos no que diz respeito ao namoro, ao casamento e à constituição da família.

Se em O demônio familiar Brito Broca vê "abolicionismo realista", no drama Mãe Alencar fez "abolicionismo romântico", na linha inaugurada pelo romance A cabana do pai Tomás, isto é, atribuindo ao escravo sentimentos como bondade, resignação, humildade.

O sucesso da peça, cuja estreia ocorreu a 24 de março de 1860, no Ginásio Dramático, consagrou Alencar como "o chefe da nossa literatura dramática", nas palavras de Machado de Assis, que considerou Mãe "o melhor de todos os dramas nacionais até hoje representados [...], uma obra verdadeiramente dramática, profundamente humana, bem concebida, bem executada, bem concluída". Como público e crítica uniram-se nos aplausos ao longo da temporada em que a peça ficou em cartaz, tudo indica que a sociedade brasileira, apesar de majoritariamente escravocrata, comoveu-se com a história da personagem Joana, a mulata que, ocultando a maternidade, é escrava do próprio filho.

Pela segunda vez, Alencar punha o escravo em cena. Se em O demônio familiar o acento era cômico, agora a intenção é explorar o drama da escravidão, a partir de uma situação potencialmente explosiva. Claro que o segredo da protagonista é o motor da peça. Joana vive com o filho Jorge em perfeita paz e harmonia, pois é efetivamente tratada como mãe, não como escrava. O rapaz, de bom coração, dá-lhe inclusive uma carta de alforria, para comemorar o aniversário de vinte e um anos. 
Nada parece ameaçar essa vida calma e o equilíbrio assentado sobre um segredo que é compartilhado apenas por um velho conhecido de Joana, há muito tempo ausente do Brasil. Mas quando a peça se inicia, a visita inesperada desse homem deixa no ar a possibilidade da revelação. $\mathrm{O}$ dr. Lima, médico, sem preconceitos, não aceita que Joana não tenha contado a verdade a Jorge.

Os desdobramentos dessa situação são cuidadosamente calculados. Para que o segredo seja revelado no momento certo e desencadeie o desfecho trágico, entram em cena dois outros personagens: Elisa e seu pai, Gomes. São vizinhos de Joana e enfrentam dificuldades financeiras, agravadas pelos ardis do agiota Peixoto, que ameaça pôr o pobre homem na cadeia se não receber certa quantia de dinheiro até o final da tarde. Como Jorge e Elisa se amam, o rapaz se sente obrigado a salvar o futuro sogro e, sem recursos, recorre ao dr. Lima, que, todavia, só poderá trazer-lhe o dinheiro na manhã do dia seguinte. A única solução vista pelo rapaz é vender Joana a Peixoto, ainda que por um dia, pois a resgataria em menos de vinte e quatro horas.

Não nos esqueçamos: Alencar quer comover. Não lhe interessa o final feliz. Assim, as cenas do quarto ato são carregadas de tensão e dramaticidade. E o momento da revelação do segredo de Joana é preparado para causar um forte impacto tanto nos personagens do drama quanto no espectador. Vejamos como os lances obedecem a uma lógica implacável. Pela manhã, Joana foge de Peixoto e vem para casa ver o filho. Em seguida chega o dr. Lima, que dá o dinheiro a Jorge, que sai à procura do agiota. Não o encontrando, volta para casa, recebe a visita de Elisa e Gomes e sai de cena para mostrar ao futuro sogro os aposentos que ocupará em breve. Enquanto isso, entra Peixoto, perguntando pela sua escrava. O dr. Lima fica indignado, mas o agiota lhe mostra o papel assinado por Jorge. O velho médico tira os olhos do papel e depara com o rapaz, que está entrando na sala, enquanto Joana aparece no fundo. A indignação explode em seus lábios: "Desgraçado! Tu vendeste tua mãe!”.

Machado de Assis, que assistiu a uma das primeiras representações, escreveu: "Eu conheço poucas frases de igual efeito. Sente-se uma contração nervosa ao ouvir aquela revelação inesperada. O lance é calculado com maestria e revela pleno conhecimento da arte no autor". 9

De fato, é impossível não concordar com Machado. O que se segue é o suicídio de Joana, lance igualmente pungente e bem preparado, pois o veneno que ela ingere pertencia a Gomes e havia sido arrancado das mãos do filho, que por sua vez o recebera de Elisa. 
Como Alencar não recorreu ao personagem raisonneur, isto é, o personagem que em cena manifesta as opiniões do autor sobre os problemas suscitados pelo enredo, em Mãe não há discursos contra a escravidão. Isso levou os críticos a se dividirem na interpretação da peça: para alguns, trata-se apenas de um elogio do sentimento materno, sem conotação antiescravista, até porque Alencar foi político do Partido Conservador; para outros, ao contrário, trata-se de uma comovente condenação do cativeiro. Recorramos mais uma vez a Machado de Assis:

Se ainda fosse preciso inspirar ao povo o horror pela instituição do cativeiro, cremos que a representação do novo drama do Sr. José de Alencar faria mais do que todos os discursos que se pudessem proferir no recinto do corpo legislativo, e isso sem que Mãe seja um drama demonstrativo e argumentador, mas pela simples impressão que produz no espírito do espectador, como convém a uma obra de arte. ${ }^{10}$

O horror a que se refere Machado pode ser observado tanto no sacrifício que Joana impõe a si mesma - viver ao lado do filho como escrava, sem revelar a verdade para não envergonhá-lo diante da sociedade preconceituosa -, quanto na cena em que Peixoto examina a "mercadoria" que está comprando. Ou, principalmente, no desfecho, pois o suicídio da protagonista é uma consequência direta dos males da escravidão.

Misturam-se na peça traços típicos do romantismo e do realismo. Joana é evidentemente uma figura idealizada. Se por um lado a sua condição social a determina enquanto personagem, por outro a sua consciência do que significa ser escrava na sociedade brasileira a transforma em uma mãe abnegada, que tudo suporta, e que é capaz de sacrificar a própria vida para que o filho não carregue o estigma da origem escrava. O lado romântico do drama estende-se também a Jorge, ao tipo de relacionamento que ele mantém com Joana, aos sentimentos que lhe dispensa. Seu comportamento não é obviamente o de um proprietário de escravos. E que dizer de sua reação ao conhecer que Joana é sua mãe? Nenhum espanto, contrariedade ou conflito interior. O bom rapaz não tem preconceitos e aceita a escrava como mãe, exprimindo o seu contentamento numa explosão de júbilo. Ou seja, Alencar pautou-se pela idealização romântica para condenar a instituição do cativeiro. Em vez da crítica direta, do discurso racional, do desfecho à maneira de $O$ demônio familiar, buscou a emoção para atingir o coração do espectador.

10 Idem, p. 419. 
Alguns meses antes da representação de Mãe, o Rio de Janeiro já havia visto no palco do Teatro São Pedro de Alcântara a primeira manifestação de "abolicionismo romântico". No dia 24 de dezembro de 1859 estreou o drama O escravo fiel, de Carlos Antônio Cordeiro. Ao contrário de Alencar, esse autor lançou mão do esquematismo melodramático para contar uma história que vou resumir em poucas linhas: Lourenço é escravo de Lemos, que está à beira da morte. Os vilões, um irmão padre e Salgado, cunhado do moribundo, querem dividir a herança, não reconhecendo a jovem Eulália como filha de Lemos. Lourenço ouve a conversa e a relata ao seu senhor, que já havia feito um testamento e o confia ao escravo. Lemos morre, mas, como Lourenço não sabe ler, guarda o testamento e começa a aprender a ler, recortando letras dos jornais. Passam-se alguns meses, período em que Eulália é vítima de toda sorte de humilhações, tornada empregada da casa de Salgado. O enredo se complica com o plano do vilão de fazer a mocinha casar-se com um feitor bronco para garantir a herança, caso algum testamento aparecesse. Lourenço, também perseguido e ameaçado, consegue finalmente aprender a ler, impede o casamento, desmascara os vilões e faz valer o testamento, que institui Eulália como herdeira dos bens do pai: ela poderá então se casar com o mocinho a quem ama. Outra cláusula do testamento dá alforria ao bom e fiel escravo Lourenço.

Do ponto de vista literário e dramático a peça é fraca, abusa dos clichês e exagera no maniqueísmo. Nesse sentido talvez se aproxime mais de A cabana do pai Tomás que Mãe, de Alencar, que é um drama, não um melodrama. Mas os males da escravidão estão presentes em sua ação dramática. Nas mãos do truculento Salgado, Lourenço sofre o tempo todo, resignado com sua condição. Antes, Lemos nunca o havia tratado mal. Machado de Assis assistiu à encenação dessa peça e apontou em sua "Revista de Teatros" os defeitos que viu na construção do enredo e na linguagem do escravo. No entanto, ressalvou: "As tendências liberais do autor, alguma coisa nacional que há, intenção de moralizar, salvaram o pensamento que tanto peca pela manifestação". ${ }^{11}$ Creio que é importante atentar ao elogio às "tendências liberais" que Machado enxergou no drama de Carlos Antônio Cordeiro. Isso pode sinalizar um diálogo do teatro com novas aspirações políticas que começam a se fazer presentes entre os brasileiros descontentes com a escravidão, instituição que é uma vergonha para o país. É sintomático que em seu comentário crítico Machado tenha observado que os aplausos recebidos pela peça se devam à repulsa pela escravidão por parte dos espectadores. Em São Paulo, em dezembro de 1861, foi encenado um drama romântico abertamente

11 Idem, p. 205. 
abolicionista: Sangue limpo, de Paulo Eiró. No prefácio ele explica que escreveu a peça para participar de um concurso promovido pelo Conservatório Dramático Paulistano em 1859: os prêmios seriam destinados "para o melhor drama original, revestido de moralidade, que tivesse por assunto alguns dos gloriosos episódios da história de nosso país" ${ }^{12}$

Paulo Eiró situou a ação dramática em São Paulo, entre os dias 25 de agosto e 7 de setembro de 1822. Sem pôr em cena as figuras históricas - apenas no último ato d. Pedro I e seu séquito atravessam o fundo do palco -, procurou não apenas enaltecer o ideal patriótico da independência, mas utilizar o pano de fundo histórico para abordar a questão da escravidão e os preconceitos raciais e sociais que decorrem dela. ${ }^{13} \mathrm{O}$ enredo gira em torno dos amores de Aires de Saldanha, filho de d. José, oficial português, e Luísa, mulata clara. Com a oposição do pai do rapaz, a trama se adensa, mas no final d. José é assassinado por um escravo que sofreu muito nas mãos de três senhores desalmados. Em seu belo livro sobre o drama romântico, Décio de Almeida Prado observa que esse escravo tem um nome simbólico, Liberato. Logo, ele deduz: "O negro mata o português para que o filho deste possa tornar-se brasileiro casando-se com uma mulata. Essa seria a experiência vital do processo de abrasileiramento que está na base da nacionalidade". ${ }^{14}$

Nacionalista e romântico, por fazer o elogio da independência do país utilizando os recursos formais do drama, Paulo Eiró contrapôs a liberdade conquistada em 1822 com a falta de liberdade dos escravos, vendo aí um forte componente dramático: "Não será dramático desenrolar a velha bandeira do Ipiranga, e nela apontar como antítese monstruosa a nódoa negra da escravidão, verme nojoso que rói a flor de nossas liberdades? Não será dramático mostrar o que fizeram nossos pais, e o que temos a fazer para coroar sua obra?". ${ }^{15}$ Eis aí o romantismo brasileiro de tinta social, que terá em Castro Alves a sua maior figura. Paulo Eiró o precede, e isso não é pouco. Ainda em 1861, em São Paulo, Rodrigo Otávio de Oliveira Menezes publica o drama Haabás, no qual encontramos mais um exemplo de "abolicionismo romântico". O protagonista é o escravo José Haabás, que teve a esposa violentada e assassinada

12 AZEVEDO, Elizabeth R. (Org.). Antologia do teatro romântico. São Paulo: Martins Fontes, 2006, p. 307.

13 Pouco antes de Paulo Eiró, em 1858 Agrário de Menezes publicou na Bahia o drama histórico Calabar. Não se trata de uma peça abolicionista; o herói é um mulato livre e a questão do preconceito racial é explorada apenas lateralmente no enredo, que põe em cena a luta dos portugueses contra os holandeses e a suposta traição do brasileiro Calabar.

14 PRADO, Décio de Almeida. O drama romântico brasileiro. São Paulo: Perspectiva, 1996, p. 169.

15 AZEVEDO, Elizabeth R. Op. cit., p. 309. 
pelo feitor da fazenda. O escravo o mata e foge. Do lugar onde se esconde vê a filha de seu senhor chegar com um bebê nos braços e abandoná-lo sobre uma pedra. Haabás salva o bebê e, vinte anos depois, sob falsa identidade, vive com o agora rapaz Henrique, num pedaço de terra que pertence aos herdeiros de seu antigo senhor. Eles são os pais de Henrique. O enredo se complica quando vemos o rapaz salvar a vida de uma mocinha cujo cavalo havia disparado. A mocinha é obviamente sua irmã e ambos se sentem atraídos um pelo outro. Não é preciso dizer que o incesto será evitado: no desfecho Haabás se dá a conhecer aos pais da mocinha, revela a história de Henrique e a família se recompõe. O escravo é recompensado com a liberdade e com as terras onde vive. Seu nobre caráter é enfim reconhecido.

O resumo do enredo não dá conta da pobreza literária da peça. Os exageros sentimentais, o maniqueísmo na construção dos personagens, o artificialismo dos diálogos, os clichês do melodrama, tudo colabora para que Haabás seja uma peça mal realizada. No entanto, sua recepção não foi tão negativa. Machado de Assis, que a resenhou, observou que de fato o livro era "tosco pela forma e brilhante pelo fundo; é uma bela ideia mal-afeiçoada e mal enunciada, o que não tira ao livro certo mérito que é forçoso reconhecer". ${ }^{16}$ Simpático às ideias liberais, Machado valoriza o conteúdo, que é francamente antiescravista, e identifica os dois fatos sobre os quais se baseia a peça: "Primeiro, a condição precária dos cativos; depois, a generosidade que pôde existir nessas almas, que Herculano diria atadas a cadáveres". É preciso explicar que Haabás, apesar de ter assassinado o feitor, não é um homem mau nem violento. Ele lamenta o tempo todo ter cometido o crime e seu arrependimento é sincero. Nos vinte anos que vive sob falsa identidade ele só faz o bem, mostra-se bom cristão, e revela o que Machado aponta como "generosidade que pode existir nessas almas", qualidade que caracteriza o protagonista de A cabana do pai Tomás. Lida pelos seus contemporâneos como peça de propaganda contra o cativeiro, Haabás mereceu a seguinte apreciação de Pessanha Póvoa, o editor da Revista Dramática publicada em 1860 pelos alunos da Faculdade de Direito do Largo de São Francisco: "Haabás é um grito contra a escravidão, é um protesto santo e justo conta a usurpação consagrada sob o título de direitos" ${ }^{17}$

Na virada da década de 1850 para a de 1860, o "abolicionismo romântico" convive com o "abolicionismo realista". Do ponto de vista da história do teatro brasileiro, nessa altura o realismo teatral é muito mais forte do que o romantismo. No Rio

16 ASSIS, Machado de. Op. cit., p. 262.

17 Apud João Roberto Faria, Ideias teatrais: o século XIX no Brasil. São Paulo: Perspectiva/Fapesp, 2001, p. 541.

104 • FARIA, João Roberto. Teatro romântico e escravidão 
de Janeiro, como já observei, pelo menos desde 1855 o Teatro Ginásio Dramático oferecia à plateia fluminense os chamados "dramas de casaca", isto é, comédias realistas que primeiramente vieram da França, mas que depois de algum tempo já eram escritas por brasileiros. Vários dramaturgos seguiram o exemplo de Alencar, que inaugurou com $O$ demônio familiar o realismo teatral na dramaturgia brasileira. Em 1861, o "abolicionismo realista” aparece em duas peças representadas no Ginásio Dramático: Sete de Setembro, de Valentim José da Silveira Lopes, português radicado no Brasil, pai da escritora Lúcia Lopes de Almeida; e em História de uma moça rica, de Pinheiro Guimarães. A primeira é uma autêntica peça de ideias a favor do trabalho livre, do pensamento liberal e contra a escravidão. O primeiro ato põe em cena uma família pobre de lavradores, formada por Raimundo, o pai; Carlos, o filho; e Maria, uma moça que Raimundo criou como filha e que havia sido abandonada à porta de sua casa quando bebê. Os diálogos entre eles nos informam que os jovens vão se casar e que o caráter de Raimundo é o de um homem trabalhador, que nunca teve escravos, que construiu seu pequeno patrimônio com o próprio trabalho. A vida dos três personagens é abalada com a denúncia de que Maria era filha de uma escrava e, portanto, "escrava também”. No segundo ato Maria está na casa de seu proprietário, um rico fazendeiro. Carlos e o pai vendem uma pequena propriedade para comprar a moça. Eis que entra em cena, vindo da Europa, formado em Direito, o filho do fazendeiro, Artur. Adepto das ideias liberais, esse rapaz representa na peça o pensamento antiescravista ilustrado, o homem brasileiro de uma futura sociedade alicerçada no trabalho livre e na ciência. Ele liberta Maria, com o consentimento do fazendeiro, numa cena que se passa no dia 7 de setembro, com tiros de artilharia ao fundo. Juntando o dia da liberdade da pátria com o gesto de Artur em relação a Maria, Silveira Lopes propõe o fim da escravidão no Brasil. Carlos, estendendo a mão a Artur, lhe diz: "Aperte esta mão, mancebo; é a mão do homem do trabalho, que se ufana de apertar a mão ao homem da ciência". ${ }^{18}$

Em artigo publicado na Revista Popular, Leonel de Alencar, irmão de José de Alencar, elogia "a maneira como o sr. Silveira Lopes apresentou-nos o homem moderno, o homem do século em que vivemos, o homem enfim do progresso e do coração liberal". ${ }^{19}$ Menos explícita na condenação do cativeiro é História de uma moça rica. A peça aborda centralmente as consequências de um casamento feito por dinheiro, em que uma jovem esposa, sofrendo todo tipo de humilhação e violência por parte do mari- 
do, foge de casa e se prostitui para sobreviver. O problema da escravidão aparece apenas no segundo ato, quando vemos em cena a mulata Bráulia aproveitando as vantagens de estar amancebada com o dono da casa. Se em $O$ demônio familiar Alencar já havia demonstrado, apelando para a leveza e a comicidade, o quanto era nociva a escravidão doméstica para a família brasileira, Pinheiro Guimarães aborda o problema de modo mais contundente, por meio da criação de uma personagem insidiosa e má. Brito Broca não hesitaria em apontar nessa peça o "abolicionismo realista”, uma vez que o caráter de Bráulia foi forjado pela sua condição de escrava. Libertar-se dessa herança colonial, pelo menos no ambiente doméstico, é o que sugere o autor, cujo porta-voz, o raisonneur dr. Roberto, define-se como "negrófilo" num diálogo no primeiro ato.

Para o leitor que me seguiu até aqui, lembremos que já me referi a sete peças teatrais, escritas entre 1857 e 1861 . O que se pode concluir, observando esse conjunto, é que coube ao teatro, não à poesia ou ao romance, chamar a atenção da sociedade para o grave problema da escravidão. Quero crer que essas peças expressam na época o pensamento e o sentimento de muitas pessoas, pois antecipam uma discussão política que se dará exatamente a partir de 1861, quando Tavares Bastos começa a publicar no Correio Mercantil do Rio de Janeiro as suas Cartas do solitário, nas quais propõe "reformas liberais em todos os assuntos". ${ }^{20}$ Ele defende a necessidade e a superioridade do trabalho livre sobre o trabalho escravo, condena veementemente a escravidão, "denuncia a longa hipocrisia com que o país encarou o problema da abolição e exige a imediata extinção do regime servil".

Publicadas em livro, as Cartas do solitário, juntamente com A escravidão no Brasil (1866), de Perdigão Malheiro, forneceram as coordenadas para o surgimento de um novo liberalismo na década de 186o. Alfredo Bosi explica:

Um pensamento liberal moderno, em tudo oposto ao pesado escravismo dos anos [18]40, pôde formular-se tanto entre políticos e intelectuais das cidades mais importantes, quanto junto a bacharéis egressos das famílias nordestinas que pouco ou nada podiam esperar do cativeiro em declínio. ${ }^{22}$

20 MARTINS, Wilson. História da inteligência brasileira. São Paulo: Cultrix/Edusp, 1977, vol. 3, p. 158.

21 Idem, p. 158.

22 BOSI, Alfredo. A escravidão entre dois liberalismos. In: Dialética da colonização. 4. ed. São Paulo: Companhia das Letras, 2003, p. 224.

106 FARIA, João Roberto. Teatro romântico e escravidão 
Que o teatro exerceu um papel fundamental nesse momento, para a formação de uma consciência abolicionista entre os brasileiros, não tenhamos dúvida. Ainda na década de 1860, pelo menos duas outras peças seguirão o mesmo caminho das outras sete aqui comentadas: Cancros sociais, de Maria Ribeiro, e Gonzaga ou A revolução de Minas, de Castro Alves.

A primeira, encenada no Rio de Janeiro em 1865, mistura elementos do romantismo e do realismo para denunciar a escravidão como uma instituição que deprava, humilha e envergonha as suas vítimas. Maria Ribeiro criou um ponto de partida baseado numa ideia nobre do protagonista, Eugênio: no dia do aniversário de quinze anos de sua filha, vai libertar uma escrava da sua terra natal, a Bahia. Quer dar à menina um exemplo de consideração e bondade para com "essa mísera classe, deserdada de todos os gozos sociais e lançada, como uma vil excrescência, fora dos círculos civilizados". ${ }^{23}$

Nessa altura, de Eugênio só sabemos que é um negociante bem-sucedido no Rio de Janeiro, um homem íntegro, generoso, bom marido, trinta e quatro anos. Ele tem todas as qualidades dos heróis das comédias realistas. O que não sabemos começa a se revelar na última cena do primeiro ato. Quando lhe é apresentada a escrava que vai libertar, finge não conhecê-la, muito constrangido e envergonhado. Mas ela o reconhece, pois um coração de mãe não se engana, mesmo que tenha sido separada do filho quando ele era um menino de cinco anos.

$\mathbf{O}$ enredo que se desenvolve ao longo dos outros três atos da peça gira em torno do segredo de Eugênio - o filho branco de uma escrava -, só conhecido pelo seu protetor, o barão de Maragogipe. Paulina, a esposa, nada sabe, claro, e todo o drama do protagonista nasce do medo de ser repudiado por ela, porque nasceu escravo, e do remorso por ter repudiado a mãe naquele primeiro encontro. A partir desse ponto o enredo se enovela, o presente se mistura ao passado, onde estão todas as explicações. Maria Ribeiro lança mão de recursos folhetinescos, apela para coincidências forçadas, afasta-se das lições do realismo teatral, deixando em segundo plano a descrição dos costumes, para privilegiar a ação e ao final salvar o protagonista: velhos papéis confirmam que à época de seu nascimento a sua mãe já havia sido libertada. Não pode, portanto, ser vítima de qualquer preconceito.

As trajetórias de Eugênio e de sua mãe, separados um do outro e vendidos por um especulador quando já eram livres, dão a medida dos sofrimentos provocados pela escravidão. A força do drama está na denúncia que faz desses sofrimentos e dos

FARIA, João Roberto (Org.). Antologia do teatro realista. São Paulo: Martins Fontes, 2006, p. 302. 
preconceitos contra o escravo, força que se sobrepõe aos defeitos da forma. Machado de Assis, que aproximou Cancros sociais de Mãe, de José de Alencar, louvou o assunto escolhido por Maria Ribeiro, observando que "na guerra feita ao flagelo da escravidão, a literatura dramática entra por grande parte". ${ }^{24}$

Como se sabe, a guerra à escravidão seduziu o grande poeta Castro Alves. Podemos dizer que Gonzaga ou A revolução de Minas é o último drama importante do romantismo, ainda que os recursos românticos e melodramáticos continuem a ser empregados por outros dramaturgos nas décadas seguintes, em muitas outras peças abolicionistas. Encenado em Salvador, no dia 7 de setembro de 1867, o drama de Castro Alves abusa da retórica condoreira e da imaginação para contar a história da Inconfidência Mineira. Sem nenhuma preocupação com a realidade histórica, coloca no centro da trama um triângulo amoroso, formado por Gonzaga, Maria Doroteia e o vilão, o visconde de Barbacena. Em torno desses personagens giram os outros, como o negro Luís, liberto por Gonzaga, e Carlota, escrava de Joaquim Silvério dos Reis. A liberdade poética autoriza o autor a combinar a luta pela liberdade da pátria à luta pela abolição da escravidão. $\mathrm{O}$ discurso antiescravista se materializa muitas vezes nas palavras de Gonzaga, com seus louvores à liberdade, e nas de Luís, que denuncia os abusos sexuais dos senhores, que lamenta ser o escravo "alguma coisa que está entre o cão e o cavalo". ${ }^{25}$ Igualmente as trajetórias de Luís e Carlota servem para denunciar a ignomínia da escravidão. Luís conta que no passado foi brutalmente separado da mulher e da filhinha. A mulher morreu e ele nunca mais viu a filha, que está moça. Claro que Carlota é sua filha e ele não sabe. Ela, por sua vez, é chantageada por Joaquim Silvério dos Reis para trair a revolução. Luís é incumbido de matar a traidora, mas, quando vai apunhalá-la, vê um rosário em seu pescoço. O reconhecimento se dá com o surrado recurso melodramático da "croix de ma mère”. Abraçam-se, mas a felicidade não é para eles. As peripécias do enredo os separam e ela morre no final. Luís a carrega nos braços, dizendo: "Deus te escolheu para a primeira vítima! Pois bem; que o teu sangue puro, caindo na face do futuro, lembre-lhe o nome dos primeiros mártires do Brasil". ${ }^{26}$

Apesar de todos os seus defeitos formais, Gonzaga ou A revolução de Minas é um drama vibrante, imbuído do mais puro romantismo. Machado de Assis, que o leu em 1868, foi um tanto condescendente na análise que fez, na conhecida carta de res-

24 ASSIS, Machado de. Op. cit., p. 369.

25 ALVES, Castro. Teatro completo. São Paulo: Martins Fontes, 2004, p. 23.

26 Idem, p. 157.

108 • FARIA, João Roberto. Teatro romântico e escravidão 
posta a José de Alencar, que lhe pediu publicamente para avaliar as obras do jovem Castro Alves. Machado viu poucos defeitos no drama. E ao considerar a figura do negro Luís, começou dizendo que "em uma conspiração para a liberdade, era justo aventar a ideia da abolição". ${ }^{27}$ Ressalta ainda que Luís e sua filha Carlota são personagens ficcionais que contracenam com os personagens históricos e que o autor os caracteriza como vítimas da escravidão, fazendo-os sofrer nas mãos de Joaquim Silvério dos Reis. Machado realça os dois sentimentos que movem o ex-escravo Luís: a paixão pela liberdade e o desespero do amor paterno. O segundo é mais forte e traz a Gonzaga uma intensidade dramática que permite ao crítico estabelecer um paralelo com Shakespeare:

[...] quando no terceiro ato Luís encontra a filha já cadáver, e prorrompe em exclamações e soluços, o coração chora com ele, e a memória, se a memória pode dominar tais comoções, nos traz aos olhos a bela cena do rei Lear, carregando nos braços Cordélia morta. Quem os compara não vê nem o rei nem o escravo: vê o homem. ${ }^{28}$

Claro que a comparação é exagerada. Mas Machado escreveu sob a impressão da leitura que o próprio Castro Alves fez a um grupo de intelectuais.

Depois da estreia em Salvador, Gonzaga ou A revolução de Minas foi encenado em São Paulo, em outubro de 1868. Nessa altura, a luta abolicionista tem a simpatia de amplos setores da sociedade brasileira e do Partido Liberal. Sabemos que a primeira vitória dessa luta se dá logo em 1871: a Lei do Ventre Livre. Nos anos que se seguiram, até 1888 , data da abolição, o teatro foi um forte aliado dos abolicionistas. Muitas peças foram escritas em todo o Brasil, dando continuidade àquelas que foram pioneiras no final da década de 1850, início da seguinte. Ao contrário do romance, é possível chegar a um número expressivo de originais que talvez não primem pela qualidade. Mas são uma prova concreta de que o teatro cavou uma trincheira de onde lutou contra a escravidão. Apenas a título de curiosidade, porque não vem ao caso estudar aqui esses originais, termino estas breves considerações deixando uma lista ${ }^{29} \mathrm{de}$ peças que foram escritas e publicadas ou eventualmente encenadas entre 1867 e 1887:

27 ASSIS, Machado de. Op. cit., p. 479.

28 Idem, p. 480 .

29 Fiz a lista - que pode ganhar acréscimos com uma pesquisa mais detalhada - consultando as seguintes obras: História da inteligência brasileira, de Wilson Martins (São Paulo, Cultrix/Edusp, 1977, vol. 3); O negro na literatura brasileira, de Raymond Sayers (Rio de Janeiro, O Cruzeiro, 1956); A personagem negra no teatro 
- Atriz escrava, de Tomás Antônio Espiúca (1867).

- O soldado brasileiro, de Cândido Barata Ribeiro e Ubaldino do Amaral (1869).

- Mulheres, de Apolinário Porto-Alegre (1869).

- Ódio de raça, de Francisco Gomes de Amorim (1869).

- O escravo, de José Tito Nabuco de Araújo (1870).

- Os pupilos do escravo, de J. P. da Costa Lima (1870).

- O escravo, de Francisco Antônio de Oliveira Sobrinho (1870).

- O escravo educado, de Brício Cardoso (1870).

- Benedito, de Apolinário Porto-Alegre (1873).

- Os filhos da desgraça, de Apolinário Porto-Alegre (1874).

- Mateus, de José de Sá Brito (1875).

- O escravo, de José Tito Nabuco de Araújo (1875).

- Os escravocratas ou a Lei de 28 de Setembro, de Fernando Pinto de Almeida Júnior (1877 ou 1885 ?).

- O negro, de Olímpio Catão (1879).

- O órfão e o escravo, de autoria desconhecida (1880).

- Escrava e mãe, de José Alves Coelho da Silva (1880 ou 1885?).

- O pai da escrava, de Manuel Joaquim Valadão (1881).

- Fantina, de Francisco Coelho Duarte Badaró (1881).

- O segredo do lar, de Cândido Barata Ribeiro (1881).

- O Liberato, de Artur Azevedo (1881).

- O escravocrata, de Artur Azevedo e Urbano Duarte (1882).

- O filho de uma escrava, de Aparício Mariense da Silva (1882).

- A escrava branca, de Júlio César Leal (1883).

- A filha da escrava, de Artur Rodrigues da Rocha (1883).

- O escravo, de José Bernardino dos Santos (1883).

- Cora, a filha de Agar, de José Cavalcanti Ribeiro da Silva (1884).

- O mulato, de Aluísio Azevedo (adaptação do romance homônimo, 1884).

brasileiro, de Miriam Garcia Mendes (São Paulo, Ática, 1982); O teatro no Brasil sob dom Pedro /l (1ª Parte. Porto Alegre, URGS/IEL, 1979). Além das peças comentadas no texto e arroladas na lista, podemos citar ainda Os mártires da escravidão, de Vicente Eufrásio da Costa (1860); O mulato, de Pires de Almeida (proibida pelo Conservatório Dramático em 1863); e Fernando, de Pires de Almeida (1864). Não consultei o manuscrito de A escrava (1863), de Araújo Porto-Alegre, que se encontra na Academia Brasileira de Letras, segundo Galante de Sousa. Será um drama antiescravista? 
- O filho da escrava, de Tutila Unzer (1886).

- Corja opulenta, de Joaquim Nunes (1887).

- A mãe dos escravos, de autoria desconhecida (1887).

- Clotilde, de Manuel Teotônio Freire (1887).

João Roberto Faria é professor de Literatura Brasileira na Universidade de São Paulo. É pesquisador do CNPq e coordenador da coleção "Dramaturgos do Brasil", da editora Martins Fontes, para a qual preparou os volumes Teatro de Álvares de Azevedo (2002), Teatro de Aluísio Azevedo e Emílio Rouède (2002), Teatro de Machado de Assis (2003), José de Alencar: Dramas (2005) e Antologia do Teatro Realista (2006). É autor dos seguintes livros: José de Alencar e o teatro (São Paulo, Perspectiva/Edusp, 1987); O teatro realista no Brasil: 1855-65 (São Paulo, Perspectiva/Edusp, 1993); O teatro na estante (São Paulo, Ateliê Editorial, 1998) e Ideias teatrais: o século XIX no Brasil (São Paulo: Perspectiva/Fapesp, 2001). Como organizador, publicou: Décio de Almeida Prado: um homem de teatro (São Paulo, Edusp/ Fapesp, 1997, em colaboração com Flávio Aguiar e Vilma Arêas); Dicionário do teatro brasileiro: temas, formas e conceitos (São Paulo: Perspectiva/sEsC, 2006, em colaboração com J. Guinsburg e Mariângela Alves de Lima); Do teatro: textos críticos e escritos diversos, de Machado de Assis (São Paulo, Perspectiva, 2008); O espelho, de Machado de Assis (Campinas, Editora da Unicamp, 2009). 